\title{
Perceptions of registered nurses in four state health insititutions on continuing formal education
}

\author{
L Richards, MA Health Studies \\ Lecturer, University of the Western Cape \\ E Potgieter, D Litt et Phil \\ Associate Professor, Department of Health Studies, Unisa.
}

\section{Kev words}

continuing formal education; registered nurse; perceptions; motivation; physical barriers; structural barriers.

\section{Correspondence address}

Prof E Potgieter

Department of Health Studies

UNISA

Tel:(012) 429-6545

Fax:(012)429-6688

E-mail:potgie@unisa.ac.za

\begin{abstract}
Curationis 33 (2): 41-50
This study investigated registered nurses in four selected state health institutions' perceptions with regard to continuing formal education. The relevance of continuing formal education is being emphasised globally by the increasing quest for quality assurance and quality management systems within an ethos of continuous improvement. According to Tholoe (2006:5), it is important to be committed to continual learning, as people's knowledge become less relevant because skills gained early in a career are insufficient to avoid costly mistakes made through ignorance. Continuing formal education in nursing is a key element to the maintenance of quality in health care delivery. The study described:

- $\quad$ registered nurses' views on continuing formal education

- $\quad$ registered nurses' perceived barriers to continuing formal education

A quantitative descriptive survey design was chosen using a questionnaire for data collection. The sample consisted of 40 registered nurses working at four state health institutions in the Western Cape Province, South Africa. Convenience sampling was selected to include registered nurses who were on duty on the days during which the researcher visited the health institutions to distribute the questionnaires. The questionnaire contained mainly closed-ended and a few open-ended questions. Content validity of the instrument was ensured by doing a thorough literature review before construction of items and a pretest. Reliability was established by the pretest and providing the same information to all respondents before completion of the questionnaires. The ethical considerations of informed consent, anonymity and confidentiality were adhered to and consent to conduct the study was obtained from relevant authorities. Descriptive statistics, based on calculations using the Microsoft (MS) Excel (for Windows 2000) programme, were used to summarise and describe the research results. The research results indicated that most registered nurses perceive continuing formal education as beneficial to their personal and professional growth and that it could lead towards improving the quality of patient/client care, but barriers exist which prevent or deter them from undertaking continuing formal education programmes. The main structural barriers included lack of funding and lack of coherent staff development planning and physical barriers including job and family responsibilities.
\end{abstract}




\begin{tabular}{|c|c|c|c|c|c|c|c|c|c|c|c|c|}
\hline \multirow{2}{*}{$\begin{array}{l}\text { Reason for engaging in con- } \\
\text { tinuing formal education }\end{array}$} & \multicolumn{2}{|c|}{$\begin{array}{cc} & \text { Agree } \\
\text { n } & \%\end{array}$} & \multicolumn{2}{|c|}{$\begin{array}{c}\text { Strongly } \\
\text { agree }\end{array}$} & \multicolumn{2}{|c|}{ Disagree } & \multicolumn{2}{|c|}{$\begin{array}{l}\text { Strongly } \\
\text { disagree }\end{array}$} & \multicolumn{2}{|c|}{ Un-answered } & $\mathbf{n}$ & $\begin{array}{c}\text { otal } \\
\%\end{array}$ \\
\hline & 12 & 30.0 & 28 & 70.0 & 0 & & 0 & & 0 & & 40 & 100 \\
\hline $\begin{array}{l}\text { To develop proficiency nec- } \\
\text { essary to meet patients' ex- } \\
\text { pectations }\end{array}$ & 9 & 22.5 & 30 & 75.0 & 1 & 2.5 & 0 & & 0 & & 40 & 100 \\
\hline $\begin{array}{l}\text { To gain knowledge and skills } \\
\text { not obtained during basic } \\
\text { training }\end{array}$ & 14 & 35.0 & 25 & 62.5 & 1 & 2.5 & 0 & & 0 & & 40 & 100 \\
\hline $\begin{array}{l}\text { To develop leadership capa- } \\
\text { bilities }\end{array}$ & 13 & 32.5 & 26 & 65.0 & 1 & 2.5 & 0 & & 0 & & 40 & 100 \\
\hline $\begin{array}{l}\text { To be an effective mentor for } \\
\text { newly qualified nurses/nurs- } \\
\text { ing students }\end{array}$ & 9 & 22.5 & 28 & 70.0 & 3 & 7.5 & 0 & & 0 & & 40 & 100 \\
\hline To improve confidence & 16 & 40.0 & 21 & 52.5 & 2 & 5.0 & 0 & & 1 & 2.5 & 40 & 100 \\
\hline To plan a career pathway & 17 & 42.5 & 20 & 50.0 & 1 & 2.5 & 2 & 5.0 & 0 & & 40 & 100 \\
\hline $\begin{array}{l}\text { To improve prospects of re- } \\
\text { muneration and promotion }\end{array}$ & 20 & 50.0 & 17 & 42.5 & 1 & 2.5 & 2 & 5.0 & 0 & & 40 & 100 \\
\hline $\begin{array}{l}\text { To network with other nurs- } \\
\text { ing colleagues }\end{array}$ & 18 & 45.0 & 9 & 22.5 & 8 & 20.0 & 3 & 7.5 & 2 & 5.0 & 40 & 100 \\
\hline $\begin{array}{l}\text { To obtain an additional } \\
\text { qualification }\end{array}$ & 5 & 12.5 & 6 & 15.0 & 10 & 25.0 & 17 & 42.5 & 2 & 5.0 & 40 & 100 \\
\hline $\begin{array}{l}\text { To provide a break from the } \\
\text { pressures of work }\end{array}$ & 7 & 17.5 & 3 & 7.5 & 17 & 42.5 & 13 & 32.5 & 0 & & 40 & 100 \\
\hline
\end{tabular}

\section{Introduction}

The World Health Report emphasises the need for strategic planning with regard to continuing education for health care providers. Human resources are the most important of the health system's resource inputs. The performance of health care systems ultimately depends on the knowledge, skills and motivation of the people responsible for delivering services. Education and training are key investment tools as old skills become obsolete with the advent of new technologies (World Health Organisation [WHO] 2000:76). The relationship between societal and technical change and subsequent pressures for reform in health care systems require nurses to constantly face increasing demands to remain professionally up to date, competent and capable to cope with the stresses and challenges in the health care environment (Peck, McCall \& Rotem 2000:432).

Professionalism relies increasingly on an ability to respond quickly to changing market conditions, to client requirements, and to the influence of government policies. Professionals are encouraged to embrace change and foster innovation. New skills essential to professional and organisational success, are needed to adapt to these changes.

The professions are increasingly at much higher risk from legal claims of negligence than in the past. Health care professionals work in a very structured environment where regulation and accountability for practice are required. Nursing deals with complex human problems, and cannot limit itself to a circumscribed body of information. In order to respond to the array of problems that nurses confront, the profession as a whole and its members individually must be encouraged to profit from every source of knowledge (Eustace 2001:134; Page 2004:29). One of the primary roles of professional bodies is to safeguard standards of competence. The South African Nursing Council determines professional 
Table 2: Motivation for engaging in continuing formal education $(\mathrm{N}=40)$

\begin{tabular}{|c|c|c|c|c|c|c|c|c|c|c|c|c|}
\hline $\begin{array}{l}\text { Motivation for engaging in } \\
\text { continuing formal education }\end{array}$ & $\mathbf{n}$ & $\begin{array}{l}\text { Igree } \\
\%\end{array}$ & & $\begin{array}{l}\text { ongly } \\
\text { gree } \\
\%\end{array}$ & & $\begin{array}{l}\text { agree } \\
\%\end{array}$ & & $\begin{array}{l}\text { ongly } \\
\text { agree } \\
\%\end{array}$ & & $\begin{array}{l}\text { answered } \\
\%\end{array}$ & $\mathbf{n}$ & $\begin{array}{c}\text { Cotal } \\
\%\end{array}$ \\
\hline $\begin{array}{l}\text { Prospects of promotion and } \\
\text { remuneration }\end{array}$ & 21 & 52.5 & 11 & 27.5 & 4 & 10.0 & 3 & 7.5 & 1 & 2.5 & 40 & 100 \\
\hline $\begin{array}{l}\text { Assistance with working out } \\
\text { a career pathway }\end{array}$ & 22 & 55.0 & 8 & 20.0 & 5 & 12.5 & 4 & 10.0 & 1 & 2.5 & 40 & 100 \\
\hline Funding assistance & 22 & 55.0 & 7 & 17.5 & 7 & 17.5 & 3 & 7.5 & 1 & 2.5 & 40 & 100 \\
\hline $\begin{array}{l}\text { Role models who demon- } \\
\text { strate the value of career de- } \\
\text { velopment }\end{array}$ & 20 & 50.0 & 9 & 22.5 & 9 & 22.5 & 1 & 2.5 & 1 & 2.5 & 40 & 100 \\
\hline $\begin{array}{l}\text { Recent success in a study } \\
\text { programme }\end{array}$ & 22 & 55.0 & 6 & 15.0 & 7 & 17.5 & 3 & 7.5 & 2 & 5.0 & 40 & 100 \\
\hline Peer encouragement & 22 & 55.0 & 5 & 12.5 & 10 & 25.0 & 2 & 5.0 & 1 & 2.5 & 40 & 100 \\
\hline $\begin{array}{l}\text { Encouragement from man- } \\
\text { agement }\end{array}$ & 21 & 52.5 & 4 & 10.0 & 11 & 27.5 & 3 & 7.5 & 1 & 2.5 & 40 & 100 \\
\hline $\begin{array}{l}\text { Obtaining a SANC qualifica- } \\
\text { tion with scarce skill allow- } \\
\text { ance }\end{array}$ & 16 & 40.0 & 9 & 22.5 & 8 & 20.0 & 6 & 15.0 & 1 & 2.5 & 40 & 100 \\
\hline $\begin{array}{l}\text { A study skills course prior } \\
\text { to commencement of a for- } \\
\text { mal programme }\end{array}$ & 19 & 47.5 & 6 & 15.0 & 9 & 22.5 & 5 & 12.5 & 1 & 2.5 & 40 & 100 \\
\hline
\end{tabular}

standards. In so doing, health care users are afforded the services of a competent professional nurse. The challenge for nurse education includes fostering the competence of the nurse to ensure that she/he can implement evidence-and-research-based practice that guides the nurse in sound decision making (Van Wyk 2006:45).

According to Myers (2001:1), the aims of continuing formal education are to maintain knowledge and skills, to improve existing competencies and to develop new competencies with the ultimate aim of improving patient care. This is affirmed by Smith \& Topping (2001:342), who view improved knowledge, improved care delivery and professional development as some of the major benefits of post registration nursing courses.

\section{Background and literature review}

The nursing profession is accountable to society for providing high-quality care for patients and families. Nurses therefore have to maintain competencies and keep up to date with the most recent research and developments in patient care. According to Smith and Topping (2001:342), professional continuing education empowers nurses to stay effective in their jobs and improve quality in health service delivery.

A review of relevant literature revealed many studies which describe the benefits of continuing formal education but several authors report that there are also barriers to continuing formal education.

\section{Benefits of continuing formal education}

Effective continuing education has been linked with raised staff morale, increased motivation and staff retention. Reasons given by nurses for engaging in continuing education include enhancement of professional knowledge; advancing professionally; providing relief from routine; improvement of social relations; and acquirement of credentials. In most circumstances continuing formal education in nursing is accompanied by the development of leadership skills evidenced by the ability to inspire followers, master uncertainty, foster confidence and accommodate criticism(Ehrat 2001:36-42; Eustace 2001:134).

Continuing formal education programmes have a range of functions comprising a maintenance role which fosters the notions of life-long learning; a survival role requiring practitioners to demonstrate their ongoing competence; and a mobility role which aims to increase a person's employability. As nursing becomes more complex nurses are required to be more knowledgeable, and the more health professionals learn the more they will challenge the traditional practices, embrace change and foster innovation (Lawton \& Wimpenny 2003:41; Eustace 2001:134; 


\begin{tabular}{|c|c|c|c|c|c|c|c|c|c|c|c|c|}
\hline \multirow{2}{*}{$\begin{array}{l}\text { Barrier to engaging in con- } \\
\text { tinuing formal education } \\
\text { Lack of funding }\end{array}$} & \multicolumn{2}{|c|}{$\begin{array}{lr} & \text { Agree } \\
\text { n } & \%\end{array}$} & \multicolumn{2}{|c|}{$\begin{array}{l}\text { Stronglyagree } \\
\text { n } \%\end{array}$} & \multicolumn{2}{|c|}{ n $\begin{array}{c}\text { Disagree } \\
\%\end{array}$} & \multicolumn{2}{|c|}{$\begin{array}{c}\begin{array}{c}\text { Strongly } \\
\text { disagree }\end{array} \\
\text { n } \%\end{array}$} & \multicolumn{2}{|c|}{$\begin{array}{l}\text { Un-answered } \\
\text { n } \%\end{array}$} & \multicolumn{2}{|c|}{$\begin{array}{cc} & \text { Total } \\
\text { n } & \%\end{array}$} \\
\hline & 19 & 47.5 & 9 & 22.5 & 8 & 20.0 & 4 & 10.0 & 0 & & 40 & 100 \\
\hline Job responsibilities & 13 & 32.5 & 14 & 35.0 & 11 & 27.5 & 2 & 5.0 & 0 & & 40 & 100 \\
\hline $\begin{array}{l}\text { Conditions attached to the } \\
\text { granting of study leave }\end{array}$ & 16 & 40.0 & 9 & 22.5 & 13 & 32.5 & 1 & 2.5 & 1 & 2.5 & 40 & 100 \\
\hline $\begin{array}{l}\text { Lack of employer co-opera- } \\
\text { tion (eg funding) }\end{array}$ & 19 & 47.5 & 5 & 12.5 & 14 & 35.0 & 1 & 2.5 & 1 & 2.5 & 40 & 100 \\
\hline $\begin{array}{l}\text { Family and child care re- } \\
\text { sponsibilities }\end{array}$ & 13 & 32.5 & 9 & 22.5 & 13 & 32.5 & 5 & 12.5 & 0 & & 40 & 100 \\
\hline $\begin{array}{l}\text { Lack of coherent staff de- } \\
\text { velopment plans by the in- } \\
\text { stitution }\end{array}$ & 18 & 45.0 & 3 & 7.5 & 18 & 45.0 & 1 & 2.5 & 0 & & 40 & 100 \\
\hline $\begin{array}{l}\text { Lack of a supportive work } \\
\text { environment }\end{array}$ & 12 & 30.0 & 8 & 20.0 & 19 & 47.5 & 1 & 2.5 & 0 & & 40 & 100 \\
\hline $\begin{array}{l}\text { Lack of opportunities for } \\
\text { promotion }\end{array}$ & 12 & 30.0 & 8 & 20.0 & 19 & 47.5 & 1 & 2.5 & 0 & & 40 & 100 \\
\hline
\end{tabular}

Hoban 2005:22).

Continuing formal education is the responsibility of the individual as well as the employing authority. The individual nurse has the right to expect the provision of training opportunities, and the employer should expect the nurse to maintain and develop the skills for which she/he is employed (Jooste 2005:53). Organisations which do not invest in the career development of their employees may discover that their organisation is characterised by unmotivated employees who are disinterested in career development and lack commitment to the organisation (WHO 2000:76).

Whether in the private or the increasingly privatised public/state sector, the competitive market edge must be focused on client care/service quality and technological innovation. This demands a high investment in developing people's skills if they are to be effective. Through continuing formal education, the knowledge base of staff is improved with the consequence of raising standards and producing a more cost-effective service. Lower levels of absenteeism and greater staff retention rates have been reported. The health care user and the health care institution both benefit when health care workers are empowered through increased competence and the accompanying confidence to take control of a job and apply autonomous decisionmaking (Smith \& Topping 2001:341-349; Gary 2002:33).

Within today's rapidly changing global world professional competence needs to be maintained. Professional competence is defined by Kennie (2000) in Enemark and Plimmer (2000:7), in terms of four components: knowledge competence - the possession of technical and/or business knowledge and the ability to apply this in practice; cognitive competence - the ability to problem solve using high level thinking skills; business competence - the ability to manage client expectations in a pro-active manner; and ethical and/or personal behavioural competence - the possession of appropriate personal and professional values and behaviours to be able to make sound judgments when confronted with ethical dilemmas in a professional context.

An affluent consumer society has developed as a result of a better informed and more sophisticated public. A consequence of this trend is that the public expect a higher duty of care and level of service from their professional advisors than in the past. The skills acquired during an initial training period may not equip new staff for this role. Continuing formal education has important implications for both professional nurses and for the general public. The public has a right to be safeguarded against malpractice, and they have an expectation that nurses will possess up-to-date knowledge and skills appropriate to the specialist field in which they practice (Ironside 2008:92).

\section{Barriers to continuing formal education}

While the literature points to the benefits of continuing formal education, there is an abundance of literature which points to barriers to continuing formal nursing education. According to Hoban (2005:24), neglect of professional and personal development will result in nursing lacking the credibility it has always been seeking. Barriers to undertaking continuing formal education have been identified in several studies and classified into three cat- 
egories.

Physical barriers (situational) refer to lack of time because of job responsibilities; family and child care responsibilities; difficulties in paying course fees; fear of losing benefits; and difficulty with numeracy and academic reading and writing skills (Penz, D'Arcy, Stewart, Kosteniuk, Morgan \& Smith 2007:59; Aoki \& Davies 2002: 902).

Attitudinal barriers (dispositional) comprise negativity due to unpleasant past experiences in academia; lack of emotional and physical energy and concern about not being able to keep up academically. The result is the nurse having low aspirations and doubts about the value of continuing formal education; low self-esteem; lack of confidence both generally and in relation to learning and lack of trust in the formal institution (Xaba \& Phillips 2001:2; Horton-Deutsch \& Mohr 2001:121126).

Structural barriers (institutional) have been identified as lack of transport; unavailability of nearby education institutions; staff shortages; lack of knowledge about learning opportunities, prohibitive entry requirements; lack of appropriate programmes; late advertising of professional educational events; lack of coherent staff development plans; difficulty in obtaining study leave; a non-inclusive style of nursing management; and lack of support from managers (Leading learning and skills [LSC] 2005:2-4; Penz et al 2007:59, 60,62).

\section{Problem statement}

In South Africa, nurses carry the burden of a public health system battling to overcome staff shortages, a growing HIV/AIDS pandemic and underresourced public health facilities which result in stressful working conditions. It is difficult to see beyond these harsh conditions to how attaining a higher nursing qualification will ease the burden of care and attract increased monetary reward. The researcher who, at the time of the study, was a facilitator for a post-registration nursing programme, periodically conducted interviews with nurses who were battling to attend classes, complete assignments and who felt de-motivated to the point of wanting to exit the programme before its completion. The comments received from these nurses included lack of support from managers and col- leagues; being overlooked for senior posts in spite of having relevant post registration qualifications; too much work stress; inability to manage study, work and family obligations; and guilt feelings about studying in the face of staff shortages in the work setting. It was against this background that this study sought to answer the following question:

What are registered nurses' perceptions of continuing formal education and what are the barriers to continuing formal education?

\section{Purpose and objectives}

The purpose of this study was to investigate the perceptions of registered nurses with regard to continuing formal education.

The objectives were to:

- Explore and describe registered nurses' perceptions of continuing formal education.

- Identify barriers to continuing formal education.

\section{Definition of terms}

A Registered nurse has completed a four year comprehensive course leading to registration with the South African Nursing Council as a nurse (general, psychiatric and community) and midwife in terms of Regulation R425 of 22 Feb 1985 as amended (Mellish \& Brink 1996:50).

Continuing formal education programmes are defined as those which lead to the registration of an additional qualification with the South African Nursing Council (Searle, Human \& Mogotlane 2009:70). In this study professional continuing education refers to formal education undertaken after registration of a first qualification including national diplomas, post basic nursing diplomas and degrees (Kotze 2008:216).

Perceptions refer to the act of having knowledge and understanding of something; an intuitive recognition of a truth (Collins English Dictionary 1992). Perceive means to apprehend with the mind, observe and understand (Concise Oxford Dictionary 1982:819). In this study, perceptions refer to registered nurses' knowledge and understanding of continuing formal education.

Barriers refer to those aspects which prevent access or progress (Collins
English Dictionary 1992). In this study, barriers refer to those physical, attitudinal and structural aspects which prevent the registered nurse from engaging in, or completing a continuing formal education programme (Leading learning and skills [LSC] 2005:2-4).

Motivate means to stimulate interest, it derives from motive which means a tendency to initiate movement, something which induces a person to act (Concise Oxford Dictionary 1982:711). Reason refers to a cause or justification (Concise Oxford Dictionary 1982:930).

\section{Research design and methodology}

A quantitative descriptive survey design, utilising a questionnaire was used to gather information about how registered nurses perceived continuing formal education and to identify the barriers to continuing formal education. According to Babbie and Mouton (2002:80), descriptive research provides a detailed picture of participants' views or engagement in specific behaviours which can then be stated in numerical terms and the frequency with which a specific characteristic or variable occurs in a sample.

\section{Population and sample}

The population comprised registered nurses employed at four state health institutions in the Western Cape Province in South Africa: two tertiary hospitals, a secondary level hospital and a primary health care clinic. The specific health institutions were chosen as a number of registered nurses employed at these institutions had accessed a post registration nursing programme and the researcher had easy geographical access to these institutions.

Convenience sampling was the method employed in this research, using the most conveniently available people as subjects in the study (Terre Blanche \& Durrheim 2002:380). Registered nurses who were on duty on the days when the researcher visited the health institutions to deliver the questionnaires were included in the sample. A total of 70 registered nurses indicated their willingness to complete the questionnaire but only 40 registered nurses completed and returned the questionnaires. Willing participants were not excluded on the basis of their not having 
accessed a continuing formal education programme as it was appreciated that they too would be able to answer the questions pertaining to the purpose and objectives of the research.

\section{The questionnaire as data collection instrument}

A 61 item closed-ended questionnaire was developed which contained sections on demographic information; reasons for engaging in continuing formal education; motivators for continuing formal education; benefits of, and perceived barriers to continuing formal education. Instructions were provided on how to complete the questionnaire using a 4 point Likert scale ranging from strongly agree to strongly disagree. The summation feature of a likert scale enables finer discriminations among respondents with different viewpoints (Polit \& Beck 2008:420).

The questionnaire was pre-tested by three registered nurses who did not form part of the research sample. The purpose of pre-testing was to identify and correct ambiguous questions, questions that people could not answer and grammatical and/or numbering errors. Where there was mutual agreement, the questionnaire was altered based on the principle that a questionnaire that could be interpreted differently by different people was unlikely to produce meaningful and reliable information.

\section{Reliability and validity Reliability}

Reliability refers to the consistency and stability with which an instrument measures a target attribute. If the same instrument is administered to different individuals at different times, the responses to the items should remain the same (Burns \& Grove 2001:396,809; Neuman 1997:138). Pre-testing of the questionnaire contributed towards reliability of the data collection instrument, measured in terms of asking about things the respondents were likely to be able to answer, and clarity of the questions (Babbie 1998:132).

\section{Validity}

Validity refers to the degree to which an instrument measures what it is intended to measure (Polit \& Beck 2008:768). Content validity refers to the degree to which an instrument has an adequate sample of items of the construct being measured. (Babbie \& Mouton 2002:123; Polit \& Beck 2008:458). To ensure content validity, a thorough study of relevant literature was done before constructing the questionnaire. Thereafter the questionnaire was presented to an experienced nurse educator at a higher education institution and to a graduate registered nurse for comments on the content validity of the instrument.

\section{Data collection and analysis}

The questionnaires were self-administered and anonymous. The registered nurses were asked to participate in the study by completing the questionnaire. Instructions in the form of a letter were attached to the questionnaire with instructions on how to complete every section of the questionnaire. The letter contained details of the purpose of the research and the process for delivering the completed questionnaires. Of the 70 questionnaires administered, 40 were completed and returned $(57.1 \%)$. The raw quantitative data were subjected to descriptive statistical analysis based on calculations using the Microsoft (MS) Excel (for Windows 2000) programme.

\section{Ethical considerations}

The ethical considerations of informed consent, confidentiality and anonymity were upheld. Survey researchers can intrude into a respondent's privacy by asking about intimate actions and personal beliefs, but the respondent decides when and to whom to reveal personal information. Respondents are likely to provide such information when they believe serious answers are needed for legitimate research purposes, and when they believe answers will remain confidential. Researchers have a duty to treat all respondents with dignity and to reduce anxiety or discomfort. Researchers are also responsible for protecting the confidentiality of data. Informed consent involves respondents agreeing to answer questions, refusing to participate in the research or to withdraw from the study at any time without being penalised (Neuman 1997:130,264,450). Permission to conduct the research was sought from the management of the participat- ing health care institutions and the research and ethics committee of the university endorsing the research. The researcher's name and the reasons for undertaking the research were made known to the respondents. They were assured that responses would only be used for research purposes. The researcher used the mechanism of a written letter attached to each questionnaire as the means of upholding the principle of informed consent. The researcher acknowledged the rights of the registered nurses not to participate in the study, and no respondent was coerced into completing the questionnaire.

Anonymity was ensured by not requiring from respondents to write their names on the questionnaires and the researcher was therefore not able to link the respondents with the information provided. Confidentiality was adhered to by not reporting the research results in a manner which could identify the respondents or the institutions involved (Babbie \& Mouton 2002:526; Polit \& Beck 2008:180).

\section{Results and Discussion}

\section{Demographic information}

The majority of respondents $80 \%$ $(n=32)$, were in the age group $36-55$ years whereas $47.5 \%(n=19)$ were married and $52.5 \%(n=21)$ were single and within these two groups $62.5 \%(n=25)$ had children. The mean number of years that the respondents had been qualified as registered nurses, was 21.15. This indicates that they were experienced nurses who should have been exposed to continuing formal education to maintain relevance in their practice. Atkinson, Atkinson, Smith, Bem and Hilgard (1990:110), propose 40-65 years as being in the "middle years" of adulthood and that these are the most productive years as men are usually at the peak of their careers and women have fewer responsibilities at home because children are growing up and they have therefore more time to devote to career activities.

The largest group of respondents occupied the post of Chief Professional Nurse $72.5 \%(n=29)$, followed by Senior Professional Nurse $12.5 \%(n=5)$, and Professional Nurse $15 \%(n=6)$. This means, the majority of respondents occupy senior-level posts and therefore have the responsibilities of lead- 
ership and management and coordinating the activities of the nursing team. A large number of the respondents had previously participated in continuing formal education as $85.0 \%(n=34)$ have a post registration qualification whereas only $15 \%(n=6)$ had not obtained a post registration qualification. However, half of the respondents $50 \%$ $(n=20)$, did not obtain a post basic qualification in the last 5 years and only $15 \%(n-6)$, were currently (during data collection for this study) undertaking a programme of study. According to Enemark (2005:20), it is presently estimated that the knowledge gained in a vocational degree course has an average useful life span of about four years. If professionals have expectations of increased managerial responsibility the need to acquire new skills and knowledge is even more acute.

\section{Reasons for engaging in continuing formal education}

Respondents had to respond to items to indicate which reasons had in the past or would in future, prompt them to engage in continuing formal education. The agreed and strongly agreed responses were combined and the results are illustrated in Table 1. The entire group of respondents $100 \% \quad(n=40)$ agreed. that they wanted to keep abreast with new developments in their areas of speciality whereas $97.5 \%$ $(n=39)$ agreed respectively that they would want to develop proficiency necessary to meet their patients' expectations, and gain knowledge and skills not required during their basic nursing training. This shows that their reasons for engaging in continuing formal education were not entirely self-centered but rather to promote the quality of nursing care to patients.

The majority of the respondents $97.5 \%$ $(n=39)$, agreed that they wanted to develop leadership capabilities whereas $92.5 \%(n=37)$ respectively agreed that they would engage in continuing formal education to effectively mentor newly qualified nurses/students; improve their confidence; plan their career pathways; and improve their prospects for remuneration. Modic and Schloesser (2006:96) contend that as adults mature, they have the potential to create a reservoir of experience that will cause them to become a rich source of learning. The respondents agreed to a lesser extent that they would like to network with other colleagues $67.5 \%$ $(\mathrm{n}=27)$, and obtain an additional qualification $27.5 \%(n=11)$. Parsons (1998) in Gary (2002:33), contends that empowered health care professionals can perform their jobs more confidently and effectively. Empowerment relates to the sense of self-worth and competence that comes from having skills and abilities to carry out the required job, skills which are acquired through a process of continuing professional development.

The reasons agreed upon for engaging in continuing formal education are congruent with the findings of Eustace (2001:134), who reports that reasons given for undertaking continuing formal education include: to enhance professional knowledge; advance professionally and acquire credentials. Ehrat (2001:36-42), states that in most circumstances, continuing professional development in nursing and the accompanying acquisition of leadership skills positively correlates with improved, demonstrated technical and general skills. This is affirmed by Hoban (2005:22), who emphasises that education allows the nurse to look at the wider issues around practice, and meeting patients' needs more efficiently.

\section{Motivation for engaging in continuing formal education}

The respondents were asked to respond to statements pertaining to what would motivate them to undertake a programme of continuing formal education (Table 2). The motivators for engaging in continuing formal education, given as a combination of agree and strongly agree responses, were: prospects of promotion and remuneration $80 \%(n=32)$; assistance with working out a career pathway $75 \%(n=30)$; funding assistance $72.5 \%(n=29)$; role models who demonstrate the value of career development $72.5 \%$ (29); recent success in a study programme $70 \%$ $(n=28)$; peer encouragement $67.5 \%$ $(n=27)$; encouragement from management $62.5 \%(n=25)$; obtaining a SANC qualification with scarce skill allowance $62.5 \%(\mathrm{n}=25)$; and a study skills course prior to commencement of a formal programme $62.5 \%(n=25)$. It appears that apart from financial and promotional motivators, supportive structures in the work environment such as assistance from management, peer encour- agement and good role models also act as strong motivators. Nolan, Owens and Nolan (1995:553), found individual motivation as one of the most significant factors contributing to participation in continuing professional development and added that it is easier to implement change when employees are highly motivated, the environmental infrastructure is supportive and the change initiative is widely accepted as relevant.

\section{Benefits of continuing formal education}

The questionnaire statements regarding the benefits of continuing formal education were applicable to the majority of the respondents $85.0 \%(n=34)$. The respondents who had never accessed a programme of study since registration $15.0 \%(n=6)$, were not able to answer this question. A closedended question was stated - whether or not respondents had benefited from a programme of continuing formal education. Respondents who concluded that continuing formal education had been beneficial $67.6 \%(n=23)$, were given the opportunity to elaborate in an open-ended question. The aspects mentioned most frequently included: financial and promotional prospects $(n=8)$; enhanced knowledge base $(n=7)$; and the development of leadership skills $(n=5)$.

Smith and Topping (2001:341-349) examined the relationship between undertaking a post-registration nursing course and the perceived benefits to the nursing practitioners. The perceived benefits were improved knowledge, improved care delivery, and professional development.

\section{Barriers to continuing formal education}

Investigating the barriers to continuing formal education could provide the means to devising innovative means to facilitate and foster a culture of lifelong learning. The results showed that respondents perceive the following as barriers to engaging in continuing formal nursing education programmes (Table 3). Lack of funding $70 \%(n=28)$; job responsibilities $67.5 \%(n=27)$; conditions attached to the granting of study leave $62.5 \%(n=25)$; lack of employer cooperation - eg. for funding $60 \%(n=24)$; family and child care re- 
sponsibilities $55 \%(n=22)$; lack of coherent staff development plans by the institution $52.5 \%(\mathrm{n}=21)$; lack of a supportive work environment $50 \%(n=20)$; and lack of opportunities for promotion $50 \%(n=20)$.

Eales (2001:2), Ferguson(1994:645-646), Kersaitis (1997:138) and Yuen (1991:1233), have described physical barriers to continuing formal education - those factors in the individual's life circumstances at any given time such as lack of time because of job responsibilities; family and child care responsibilities; and difficulties in paying course fees. Hoban (2005:23), points out that inadequate funding is a contentious issue and argues that health institutions cannot afford to send staff away for long periods of time as there is no point in having highly trained nurses if there is no one left to care for patients. However, to be empowered is to have access to the information, resources and support necessary for competent patient care, and to have the self-worth that comes from having the skills and the ability to carry out the required job (Gary 2002:34).

Structural barriers to continuing formal education referring to the practices, procedures and policies that place limits on opportunities for potential adult learners, have been identified as lack of coherent staff development plans; difficulty in obtaining study leave; a non-inclusive style of nursing management; and lack of support from managers (Leading learning and skills [LSC] 2005:2-4; Penzet al 2007:59, 60, 62). The lack of a supportive working environment and lack of opportunities for professional growth are cited as deterrents to continuing formal education. Some nurses feel that there is little space for them to grow in their profession in South Africa, complaining about the lack of opportunities for promotion, the difficulty in getting study leave, and nursing education not being subsidised, leading them to choose to emigrate (Xaba and Phillips 2001:1-7).

According to Bester and Mouton (2006:51), employees must get sufficient opportunities to realise their full potential and to experience job satisfaction and job involvement. Jooste (2003:150) strongly supports this view by referring to people as the greatest asset of any organisation and states that they must be cared for and valued as employees and not manipulated.

\section{Conclusion}

The findings of this study revealed that registered nurses recognise the benefits of continuing formal education not only for themselves but also for the patients, as the main reasons provided for pursuing continuing formal education were to keep abreast with developments in areas of speciality and to develop the necessary proficiency to meet patients' needs. There was also strong evidence that the participants in this study, the majority of them being in senior positions ( $85 \%$ ), want to develop leadership capabilities and be effective mentors for junior staff. The planning of career pathways and improving prospects of remuneration and promotion, were indicated as reasons but also as the strongest motivators for engaging in continuing formal education. The availability of funding and support within the work setting (through role models demonstrating the value of career development and encouragement from peers and management), also seem to be strong motivators for engaging in continuing formal education.

In this study the main barriers to continuing formal education appear to be physical barriers which refer to lack of funding, job and family responsibilities; and structural barriers, which include conditions attached to granting study leave, lack of coherent staff development plans and opportunities for promotion, and lack of a supportive work environment. However, it does appear that some institutions do have staff development plans, support their staff and provide opportunities for promotion as only $50 \%$ respondents indicated these as barriers. Recognition of the barriers to continuing formal education demands a collective response from the health care institution, the individual nurse and the nurse manager in order to overcome these barriers.

To address the nurse's career goals, both organisations and individuals should share responsibility for the careers of employees. Nurses are likely to have more successful careers if organisations and individuals are involved in career planning and management. Plans have to be put in place by nurse unit managers and organisational management to make provision in their budgets for registered nurses to access continuing formal education programmes.

According to Hoban (2005:24), lifelong learning should be about improving patient care and service delivery and the enhancement of inter-professional practice. Ultimately it is the health care user, the health care profession and the employing organisation that will benefit from continuing education. The more health professionals learn, the more they will challenge traditional practices, embrace change and foster innovation.

\section{Limitations of the study}

A limitation of the study was the response rate of $57 \%(n=40)$ which impedes the generalisation of the research results. Generalisation of the research results is further limited because the study was conducted in only four health care institutions. However, there is both a possibility and a need for the research to be replicated in other health care institutions across other provinces in South Africa.

\section{Recommendations}

The following recommendations are made:

- $\quad$ The majority of registered nurses in this study were in the 46-55 year age range. The average age the nurse in this study was qualified was 21.15 years. The aging nursing work force is a factor that nursing and organisational management would do well to consider as they plan strategies to retain a younger mobile workforce through programmes of continuing formal education while ensuring the older work force maintains relevancy in their practice.

- Organisations should create a culture of valuing continuing formal education and emphasise the need for senior staff to act as role models in this respect. Nurses need to be motivated in a supportive environment through the availability of managerial positions, promotion opportunities and flexible work schedules. 
Health service managers and educators should be aware of the need for adjustable, flexible work and course schedules to accommodate potential learners and therefore consult with each other with regards to the planning of post-registration courses. Inflexible work schedules result in not having access to professional growth opportunities which is a factor influencing nursing staff turnover (Shader, Broome, Broome, West \& Nash 2001:211).

- Registered nurses should be encouraged to use their appraisals as managers are obliged to identify the nurse's learning needs, interpersonal development needs, and plan how these needs will be met.

- $\quad$ Combining specific job-related skills training with an individualised continuing formal education programme, drawn up during the annual performance review process, has the dual advantage of showing staff how valued they are as individuals and of equipping them to move into new roles in the organisation (Hoban 2005:24).

\section{References}

AOKI, Y \& DAVIES, S 2002: Survey of continuing education within nursing homes. British Medical Journal. 11(13):902-912, July.

ATKINSON, RL; ATKINSON, CA; SMITH, EE; BEM, DJ \& HILGARD, ER 1990: Introduction to psychology. $10^{\text {th }}$ edition. Fort Worth: Harcourt brace Jovanovich College Publishers.

BABBIE, E 1998: The practice of social research. $8^{\text {th }}$ edition. Belmont, CA: Wadsworth.

BABBIE, E \& MOUTON, J 2002: The practice of social research. Cape Town: Oxford University Press Southern Africa.

BESTER, CL \& MOUTON, T 2006: Differences regarding job satisfaction and job involvement of psychologists with different dominant career anchors. Curationis. 29(3): 50-55, August.
BURNARD,P \& MORRISON,P 1994: Nursing research in action. Developing basic skills. $2^{\text {th }}$ edition. London: MacMillan.

BURNS, N \& GROVE, SK 2001: The practice of nursing research: conduct, critique and utilization. $4^{\text {th }}$ edition. Philadelphia: WB Saunders.

COLLINS ENGLISH DICTIONARY 1992. Glasgow: Harper Collins Publishers.

\section{CONCISE OXFORD DICTIONARY}

1982: Oxford: Oxford University Press.

EALES, CJ 2001: Lifelong learning. South African Journal of Physiotherapy, 57(3):2.

EHRAT, S 2001: Executive nurse career progression: Skills, wisdom and realities. Nursing Administration Ouarterly. 25(4):36-42.

ENEMARK, S \& PLIMMER, F 2000: Mutual recognition of professional qualifications in the surveying profession. International Federation of Surveyors: International Conference. http:/ Lwww.fig net/pub/proceedings/ prague-final- papers/enemarkplimmer.htm. (Accessed 5 November 2008).

ENEMARK, S 2005: Global trends in surveying education - and the role of FIG (International Federation of Surveyors). Asumuth 43, 2005:19-21. www.fig.net/council/presidentenemark.htm. (Accessed 11 November 2008).

EUSTACE, LW 2001: Mandatory continuing education: Past, present, and future trends and issues. The Journal of Continuing Education in Nursing. 32 (3):133-137, May/June.

FERGUSON, A 1994: Evaluating the purpose and benefits of continuing education in nursing and the implications for the provision of continuing education for cancer nurses. Journal of Advanced Nursing. 19:640-646.

GARY, DL 2002: Invest in yourself. The why and wherefore of empowerment: The key to job satisfaction and professional advancement. Nursing
Forum. 37(3):33-36, July/ September.

HOBAN, V 2005: The continuing professional development challenge. Nursing Times, 101(8):22-24.

HORTON-DEUTSCH, SL \& MOHR, WK 2001: The fading of nursing leadership. Nursing Outlook. 49(3):121-126.

IRONSIDE, PM 2008: Safeguarding patients through continuing competency. The Journal of Continuing Education in Nursing, 39(2):92-93.

JOOSTE, K (Ed) 2003: Leadership in health services management. Kenwyn: Juta.

JOOSTE, K 2005: The career goals of nurses in some health care settings in Gauteng. Curationis. 28(3):47-53.

KERSAITIS, C 1997: Attitudes and participation of registered nurses in continuing professional education in New South Wales, Australia. The Journal of Continuing Education in Nursing, 28(3): 135-139, May/June.

KOTZE, K (EDITOR) 2008: Nurse educators' guide to management. Pretoria: Van Schaik.

LAWTON, S \& WIMPENNY, P 2003: Continuing professional development: Areview. Nursing Standard, 17(24):4144.

\section{LEADINGLEARNINGAND SKILLS}

[LSC] 2005: What are the barriers to engaging adult learners? Skills and education network. http://senet.lsc.gov.uk (Accessed 12 August 2006).

MELLISH, JM \& BRINK, H 1996: Teaching the practice of nursing. A test in didactics. $3^{\text {rd }}$ edition. Johannesburg: Heinemann.

MYERS, G 2001: Evidence-based information literacy for continuing professional development. Johannesburg: University of Witwatersrand.

MODIC, MB \& SCHLOESSER, M 2006: Preceptorship, 22(2):96-97, March/April. Lippincott, Williams \& Wilkins.

NEUMAN, WL 1997: Social research methods. Qualitative and quantitative 
approaches. $3^{\text {rd }}$ edition. Boston: Allyn \& Bacon.

\section{NOLAN, M; OWENS, RG \& NOLAN,} J 1995: Continuing professional education: Identifying the characteristics of an effective system. Journal of Advanced Nursing, 21:551-560.

PAGE, A (EDITOR) 2004: Keeping patients safe: Transforming the work environment of nurses. Committee on the work environment for nurses and patient safety. Board on Health Care Services. Institute of Medicine of the National Academies Washington DC: The National Academies Press.

PECK, C; MCCALL, M \& ROTEM, T 2000: Continuing medical education and continuing professional development: International comparisons. British Medical Journal. (320):432-435, 12 February.

PENZ, K; D'ARCY,C; STEWART, N; KOSTENIUK, J; MORGAN, D \& SMITH, B 2007: Barriers to participation in continuing education activities among rural and remote nurses. The Journal of Continuing Education in Nursing. 38(2):58-67.

POLIT, DF \& BECK, CT 2008: Nursing research: generating and assessing evidence for nursing practice. 8th edition. Philadelphia: Wolters Kluwer/ Lippincott, Williams \& Wilkens.

SEARLE, C; HUMAN, S \& MOGOTLANE, SM 2009: Professional practice. A Southern African nursing perspective. $5^{\text {th }}$ edition. Johannesburg: Heinemann Publishers (Pty) Ltd.

SHADER, K; BROOME, ME; BROOME, CD; WEST, ME \& NASH, $M$ 2001: Factors influencing satisfaction and anticipated turnover for nurses in an academic medical center. JONA. 91(4):210-216.

SMITH, J \& TOPPING, A 2001: Unpacking the "value added" impact of continuing professional education: A multi-method case study approach. Nurse Education Today, (21):341-349.

TERRE BLANCHE,M\&DURRHEIM, K 2002: Research in practice. Cape Town: University of Cape Town Press.
TLHOLOE, MM 2006: Role of nurse managers as executives. Nursing Update, 30(8):5. Pretoria: Denosa.

VAN WYK, NC 2006: Nursing by degrees. Nursing Update. 30(4):45-47, May. Pretoria: Denosa.

WORLD HEALTH ORGANISATION 2000: The World Health Report. Health systems: Improving performance. Geneva: World Health Organisation.

XABA, J \& PHILLIPS, G 2001: Understanding nurse emigration: Trade Union Research Report, 1-7:19 June.

YEUN, F 1991: Continuing nursing education: Some issues. Journal of Advanced Nursing. 16:1233-1237. 